\title{
EFFECT OF IRRIGATION SCHEDULING AND DIFFERENT NITROGEN LEVELS ON WATER RELATION, YIELD AND YIELD COMPONENTS FOR WHEAT CROP GROWN IN MIDDLE EGYPT (GIZA REGION) \\ Poraas, M. M. E.; M. A. Mahmoud and Namait Allah Y. Osman \\ Soils, Water and Environ. Res. Inst., Agric. Res. Center, Giza, Egypt
}

\begin{abstract}
Two field experiments were executed during the two successive seasons of 2005/2006 and 2006/2007at Giza Agricultural Research Station to identify the most effective coefficient of daily pan evaporation accumulation selected from 1.25, 1.00 and 0.75 evaporation pan coefficient (EPC) in scheduling irrigation for wheat, cultivar Sakha 69, receiving 60, 75 and $90 \mathrm{~kg} \mathrm{~N} / \mathrm{fed}$ in order to maximize crop and water productivity. The number of applied irrigations and water consumptive use $(\mathrm{Cu})$ were increased as the value of EPC increased and, Cu differed significantly due to nitrogen level, with $90 \mathrm{~kg} \mathrm{~N} / \mathrm{fed}$ consuming more water than the other $\mathrm{N}$-levels. The highest Water Use Efficiency (WUE) was recorded under 1.00 EPC comparable to the other tested EPC values and values of WUE, differed due to nitrogen level. The $90 \mathrm{~kg} \mathrm{~N} / \mathrm{fed}$ gave the lowest WUE while $75 \mathrm{~kg} \mathrm{~N} / \mathrm{fed}$ gave the highest value. The plant height, grain weight/spike, number of spike/ $\mathrm{m}^{2}$ and 1000 -grain weight were significantly affected due to the adopted irrigation regimes and generally, tended to increase as EPC increased. Grain and straw yields tended to increase with increasing EPC. The highest values were obtained with 1.25 EPC. All of agronomic yields and yield components were increased with the increase in $\mathrm{N}$ - level, as well as with the increase in EPC values. The maximum values of yields and their components were given by 90 $\mathrm{kg} \mathrm{N} /$ fed with1.25 EPC.
\end{abstract}

\section{INTRODUCTION}

Wheat is the most important cereal crop used as a major food crop in Egypt, but local production dose not meet the consumption owing to the increased population with limited cultivated area as well as water resources (El-Shaer et al. 1997 and Eid et al. 1999). Therefore, Egypt would have to find new ways to increase agriculture productivity as an essential national target to fill the gab between production and consumption of wheat. This goal could be achieved by growing more high-yielding cultivars and improving the agronomic factors such as irrigation and fertilizer application.

Irrigation water has to be added timely and sufficiently (with least losses). This is difficult to be achieved in old arable lands in Egypt. One of most efficient irrigation technical methods which does this, is scheduling irrigation using evaporation pan. Moreover mathematical models study to calculate ETO, ET crop and water requirements under Egyptian conditions must be increased to meet the changes in the weather factor affecting water consumption by plant as temperature, rain, solar radiation and sunshine. Early in USA, Jensen and Midleton (1965) carried out studies scheduling crop irrigation via daily records of evaporation pan. In this respect, Abdel-Ghani et al. (1994), Shahin and Mosa (1994) stated that exposing wheat crop to high moisture stress was associated with a decrease in seasonal consumptive 
use. Rayan et al. (1999) in Upper Egypt and El-Marsafawy (2000) in Middle Egypt (Giza) used the evaporation pan method to schedule irrigation for wheat via daily accumulative records of class A-pan, to assess water productivity. Pandey et al. (2001) studied wheat response to differential seasonal irrigation regimes ranging from 300 to $690 \mathrm{~mm}$ applied water for two growing seasons and found that water use increased rather linearly with increased seasonal irrigation. Khalil et al. (2005) stated that irrigating wheat at 1.2 evaporation pan coefficient (EPC) in Upper Egypt (Shandaweel) recorded the highest water consumptive uses (Uc) in comparison with 0.8 and 1.0 EPC, with Uc values of 1582, 1797 and $2216 \mathrm{~m}^{3} / \mathrm{fed}$, for irrigation treatments at $0.8,1.0$ and 1.2 EPC, respectively, however $0.8 \mathrm{EPC}$ gave the highest water use efficiency(WUE). Salem et al. (2006) in the Delta region of Egypt (Bahteem) reported that $\mathrm{Cu}$ and WUE for wheat were highest with 1.2 EPC more than either 0.8 or 1.0 EPC. With respect to crop productivity as a function for soil moisture availability during the growing season, Mohamed and Tammam (1999), Sidrak (2003) and Moussa and Abdel-Maksoud (2004) reported that the number of spikes $/ \mathrm{m}^{2}, 1000$-grain weight, straw and grain yields decreased due to irrigation after higher soil moisture depletion.. ElMarsafawy (2000) and Rayan et al. (2000) found that the highest values of grain yield were obtained when wheat crop irrigated at 1.0 evaporation pan coefficient (EPC) compared with 0.6 and 1.4 EPC. El - Sabbagh et al. (2002) in Egypt and Metin and Attila (2006) in the arid Southeast Anatolia of Turkey, recorded that short irrigation intervals $(7.14$ and 21 days) increased plant height, spike length, number of spikes $/ \mathrm{m}^{2}$, number and weight of grain/spike, 1000- grain weight, harvest index and straw and grain yields compared with prolonged irrigation intervals (35 days) .Nitrogen fertilizer is very important for all plants, and it promotes the vegetative growth and increases the protein content in cereals. The imbalances in fertilizer application can reduce fertilizer use efficiency by 20 to $50 \%$, and only a package of agronomic practices will result in the highest effectiveness of fertilizers in food production (FAO, 1980). Singh et al. (1996) and Abou-Ahmed (1999) reported that WUE for winter wheat increased with increasing $\mathrm{N}$ - application. Angus and Van Herwaarden (2001) stated that seasonal water use of wheat was increased by $23 \mathrm{~mm}$ due to providing optimum $\mathrm{N}$ fertilizer. Wenlong et al. (2004) stated that WUE increased with increasing applied $\mathrm{N}$ - fertilizer using four $\mathrm{N}$ - levels of Zero, 124, 248 and $372 \mathrm{~kg} \mathrm{~N}^{-1}$ for wheat in semi-arid regions. Awad et al. (2000), Pandey et al. (2001) and Angus and Van Herwaarden (2001) studied wheat response to $5 \mathrm{~N}$ levels of $0,40,80,120$ and $160 \mathrm{~kg} \mathrm{~N} \mathrm{ha}^{-1}$. Responding of grain yield, spikes $\mathrm{m}^{-2}$, kernels spike ${ }^{-1}$, number of kernel $\mathrm{m}^{-2}$ and kernel weight to increases in $\mathrm{N}$ levels was positive for both growing seasons particularly at the higher N- rates. Fischer et al. (2002) in the subhumid tropical highlands in the central highlands of Mexico, Lewandowski and Kauter (2003) in South- West, Germany and lqbal et al. (2005) in NorthWest Pakistan, recorded that applying 60 or $70 \mathrm{~kg} \mathrm{~N} \mathrm{ha}^{-1}$ increased grain yield and nitrogen uptake for wheat compared with the zero or $30 \mathrm{~kg} \mathrm{~N} \mathrm{ha}^{-1}$

The main objective of the present trial is to determine the most effective of irrigation regimes (by scheduling irrigation using accumulation evaporation pan coefficient method) under different fertilizer - $\mathrm{N}$ levels in 
order to obtain improved water relation, yield and yield components for wheat, cultivar Sakha 69, under Giza region condition.

\section{MATERIALS AND METHODS}

Two field experiments were carried out at Giza Agricultural Research Station, ARC, Giza -Egypt, during 2005/2006 and 2006/2007 growing seasons to study the effect of irrigation scheduling and different applied nitrogen levels on water relation, yield and yield components for wheat grown in middle Egypt. Potential evapotranspiration ETO was estimated using three ET formulas, i.e. Modified Penman, Penman Monteih and Doorenbos-Pruitt, then compared with actual ET determination by evaporation pan to evaluate the most efficient of these formulas in calculating ET0 for wheat crop grown under Giza region condition in Middle Egypt.

The experiment was laid out in a split - plot factorial design with three replicates. The plot area was $15.0 \mathrm{~m}^{2}(3 \times 5 \mathrm{~m})$. The main plots were devoted to irrigation pan coefficient treatments and the sub plots were assigned to the nitrogen level treatments.

The experimental factors and treatments were as follows:

Factor A (Main plots) : irrigation regime (evaporation pan coefficient "EPC"):

$11-1.25$ EPC.

12- 1.00 EPC.

13- 0.75 EPC.

Factor B (Sub plots): fertilizer nitrogen levels:

$1-60 \mathrm{~kg} \mathrm{~N} /$ fed

2- $75 \mathrm{~kg} \mathrm{~N} /$ fed.

3- $90 \mathrm{~kg} \mathrm{~N} /$ fed.

Sowing dates were $8^{\text {th }}$ Dec., 2004 and $1^{\text {st }}$ Dec., 2005 for the first and second seasons, respectively. Plants were harvested on $6^{\text {th }}$ May 2006 and $2^{\text {nd }}$ May 2007 for each season, respectively. The preceding crop to wheat was sunflower in both seasons.

Irrigation was practiced according to the cumulative values of the daily evaporation records from class A pan established in Giza Agroclimatological Station for the different irrigation treatments. Application of irrigation regime treatments started from the third irrigation. The fertilizer nitrogen was applied in the form of ammonium nitrate $(33.5 \% \mathrm{~N})$ in two equal portions; the first portion was applied immediately before the life irrigation (ElMohayah irrigation) and the second one after 21 days from the first one. All other practices were applied as adopted in the area and region of the study.

Table (1): Soil moisture constants ( $\%$ by weight) and bulk density $\left(\mathrm{g} / \mathrm{cm}^{3}\right)$ of soil of the experimental site at Giza Agricultural Research Station

\begin{tabular}{|c|c|c|c|c|}
\hline Depth, cm & Field capacity \% & $\begin{array}{c}\text { Wilting point } \\
\%\end{array}$ & $\begin{array}{c}\text { Available } \\
\text { water \% }\end{array}$ & $\begin{array}{c}\text { Bulk } \\
\text { density }\left(\mathbf{g} / \mathbf{c m}^{\mathbf{3}}\right)\end{array}$ \\
\hline $00-15$ & 41.85 & 18.61 & 23.24 & 1.15 \\
$15-30$ & 33.68 & 17.50 & 16.18 & 1.20 \\
$30-45$ & 28.38 & 16.92 & 11.46 & 1.22 \\
$45-60$ & 28.05 & 16.54 & 11.51 & 1.28 \\
\hline
\end{tabular}


Weather Data used in calculating actual and potential water consumptive use were collected from Meteorological Giza station during the growing seasons as shown in Table (2).

Table (2): Some meteorological data at Giza Agricultural Research Station, 2005/2006 and 2006/2007 seasons

\begin{tabular}{|l|c|c|c|c|c|c|c|c|}
\hline & \multicolumn{7}{|c|}{ 2005/2006season } \\
\hline Month & T max & T min & RH & WS & RF & SS & SR & E pan \\
\hline Dec. & 20.0 & 7.4 & 53.0 & 2.1 & 1.0 & 7.0 & 268 & 2.3 \\
\hline Jan. & 20.4 & 8.0 & 57.0 & 2.0 & 1.9 & 7.0 & 280 & 2.1 \\
\hline Feb. & 22.8 & 10.0 & 55.0 & 2.6 & 6.0 & 7.9 & 354 & 2.7 \\
\hline Mar. & 24.6 & 10.5 & 49.0 & 2.9 & 6.6 & 8.6 & 441 & 3.4 \\
\hline Apr. & 28.7 & 16.0 & 48.0 & 3.3 & 2.0 & 9.6 & 519 & 4.7 \\
\hline May & 32.7 & 19.6 & 47.0 & 3.9 & 0.0 & 10.8 & 585 & 6.3 \\
\hline \multicolumn{8}{|c|}{$\mathbf{2 0 0 6 / 2 0 0 7}$ season } \\
\hline Dec. & 23.2 & 10.1 & 55.0 & 2.4 & 0.6 & 7.0 & 268 & 2.3 \\
\hline Jan. & 20,3 & 7,5 & 60 & 2.0 & 2.4 & 7.0 & 280 & 1,9 \\
\hline Feb. & 20,7 & 7,1 & 60 & 2.3 & 8.0 & 7.9 & 354 & 2,9 \\
\hline Mar. & 25,5 & 10,7 & 57 & 3.4 & 3.1 & 8.6 & 441 & 3,4 \\
\hline Apr. & 32,8 & 17,3 & 58 & 4.1 & 0.0 & 9.6 & 519 & 5.1 \\
\hline May & 31,9 & 16,7 & 54 & 3.7 & 0.0 & 10.8 & 585 & 8,3 \\
\hline
\end{tabular}

$\mathrm{T}$ max and $\mathrm{T}$ min $=$ maximum and minimum temperatures, ${ }^{\circ} \mathrm{C} ; \mathrm{WS}=$ wind $\mathrm{speed}, \mathrm{m} / \mathrm{Sec}$ $\mathbf{R H}=$ relative humidity $\% ; \mathbf{R F}=$ rain fall, $\mathbf{m m} ; \mathbf{S S}=$ actual sun shine, $\mathrm{hrs} ; \mathrm{SR}=$ solar radiation, cal $/ \mathrm{cm}^{2} / \mathrm{day} ; \mathrm{Ep}=$ pan evaporation , $\mathrm{mm} / \mathrm{day}$.

Table (3): Date of different irrigation regimes of the current experiment for the wheat crop grown in Giza region in 2004/2005 and 2005/2006 seasons

\begin{tabular}{|l|c|c|c|c|c|c|c|c|c|}
\hline \multirow{2}{*}{ Season } & $\begin{array}{c}\text { Irrigation } \\
\text { regime }\end{array}$ & $\begin{array}{c}\text { Evapor. } \\
\text { "EPC' }\end{array}$ & $\begin{array}{c}\text { First } \\
\text { Irri. }\end{array}$ & $\begin{array}{c}\text { Secod } \\
\text { Irri. }\end{array}$ & $\begin{array}{c}\text { Third } \\
\text { Irri. }\end{array}$ & $\begin{array}{c}\text { Fourt } \\
\mathbf{h} \\
\text { Irri. }\end{array}$ & $\begin{array}{c}\text { Fifth } \\
\text { Irri. }\end{array}$ & $\begin{array}{c}\text { Sixth } \\
\text { Irri. }\end{array}$ & $\begin{array}{c}\text { Seventh } \\
\text { Irri }\end{array}$ \\
\hline \multirow{2}{*}{$2005 / 2006$} & 1.25 & 82.5 & $8 / 12$ & $4 / 1$ & $3 / 2$ & $19 / 2$ & $14 / 3$ & $29 / 3$ & $12 / 4$ \\
\cline { 4 - 10 } & 1.00 & 110.0 & $8 / 12$ & $4 / 1$ & $9 / 2$ & $1 / 3$ & $23 / 3$ & $12 / 4$ & \\
\cline { 4 - 10 } $2006 / 2007$ & 0.75 & 137.5 & $8 / 12$ & $4 / 1$ & $14 / 2$ & $6 / 3$ & $6 / 4$ & & \\
& 1.25 & 82.5 & $1 / 12$ & $28 / 12$ & $27 / 1$ & $16 / 2$ & $7 / 3$ & $23 / 3$ & $6 / 4$ \\
\cline { 4 - 9 } & 1.00 & 110.0 & $1 / 12$ & $28 / 12$ & $3 / 2$ & $26 / 2$ & $23 / 3$ & $11 / 4$ & \\
\cline { 4 - 9 } & 0.75 & 137.5 & $1 / 12$ & $28 / 12$ & $9 / 2$ & $20 / 3$ & $15 / 4$ & & \\
\hline
\end{tabular}

The results were presented and discussed as follow:

\section{A- Water relations:}

1- Actual water consumptive use 'CU' (Actual evapotranspiration):

Water consumptive use was determined via soil samples from the sub plots just before each irrigation and 48 hrs later besides at harvest, in 15 $\mathrm{cm}$ segments along the $60 \mathrm{~cm}$ depth of the soil. The CU was calculated according to Israelsen and Hansen (1962) as follows:

\section{Where:}

$$
C U=D \times B d \times Q_{2}-Q_{1} / 100
$$
CU
= actual evapotranspiration (i.e., actual consumptive use) (in $\mathrm{mm}$ )
$\mathrm{D} \quad=$ the irrigation soil depth. (in $\mathrm{mm}$ ) 
$\mathrm{Bd} \quad=$ bulk density of soil $\left(\mathrm{g} / \mathrm{cm}^{3}\right)$.

$\mathrm{Q}_{2} \quad=$ the percentage of soil moisture two days after irrigation (\% w/w).

$\mathrm{Q}_{1} \quad=$ the percentage of soil moisture before next irrigation $(\% \mathrm{w} / \mathrm{w})$.

2- Water use effcicincy ( WUE):

Water use efficiency in the present work, refers to the amount of wheat grains $(\mathrm{kg})$ produced due to $1 \mathrm{~m}^{3}$ of water consumed, estimated according to Vites (1965) as follows: -

$$
\text { WUE }=\frac{\text { Grain yield }(\mathrm{kg} / \mathrm{fed})}{\text { Seasonal ET }\left(\mathrm{m}^{3} / \mathrm{fed}\right)}
$$

\section{3- Potential evapotranspiration estimated by some ET formulas:}

The "WATER" model (Zazueta and Smajstrla, 1984) was used for estimation of potential evapotranspiration by the Modified Penman, Doorenbos- Pruitt methods whereas the CROPWAT 4.3 model was used to estimate potential evapotranspiration by the Penman Monteith method.

\section{B- Growth, yield and some yield attributes:}

At harvest, the plants of each entire sub-plot were sampled in order to determine plant height, straw and grain yields. The number of spikes $/ \mathrm{m}^{2}$ was determined by counting all spikes per square meter selected in random from each sub-plot. Ten spikes were randomly taken, from each sub-plot, and weight of grains / spike and 1000-grain weight were determined, then plots were harvested and yields were measured. Data of growth, yield and yield components were subjected to statistical analysis of variance as described by Sendecor and Cochoran (1980).

\section{RESULTS AND DISCUSSION}

\section{Water relations}

\section{1-1. Actual water consumptive use (Actual evapotranspiration):}

Evapotranspiration is the combination of two processes, evaporation and transpiration. Evaporation is direct evaporation of water from the soil surface and/or from the plant surface. Transpiration is the flow of water vapor from the interior of the plant to the atmosphere (Jones et al., 1984).

Results in Table (4) show that seasonal water consumptive use ETa was increased as EPC value increased, since the ETa value under the 1.25 EPC treatment was increased by 10.48 and $25.21 \%$ more than those under 1.00 and 0.75 EPC treatments, respectively in the first season. In the second season, similar trend was observed with increases reached to 10.55 and $21.20 \%$, respectively, for 1.25 EPC treatment compared to 1.00 and 0.75 EPC treatments .Two seasons results reveal that, regardless of $\mathrm{N}$ - level, water consumptive use was increased as EPC value increased. These results may be attributed to the increase in number of irrigations and to that the soil moisture was more available for extraction by plant roots and as well as soil surface evaporation. These results are in the harmony with those obtained by Moussa and Abdel-Maksoud (2004). 
Poraas, M. M. E. et al.

Table (4): Seasonal water consumptive use $(\mathrm{mm})$ of wheat cultivar Sakha69 as affected by irrigation regime and $\mathbf{N}$ fertilizer levels at Giza region in $2005 / 2006$ and 2006/2007 seasons

\begin{tabular}{|c|c|c|c|c|c|c|c|c|}
\hline \multirow{3}{*}{\begin{tabular}{|l} 
seasons \\
Irrigation \\
Regime
\end{tabular}} & \multicolumn{4}{|c|}{$2005 / 2006$} & \multicolumn{4}{|c|}{$2006 / 2007$} \\
\hline & \multicolumn{8}{|c|}{$\mathrm{N}$ - levels ( kq/ fed) } \\
\hline & 60 & 75 & 90 & Mean & 60 & 75 & 90 & Mean \\
\hline \multicolumn{9}{|c|}{ Water consumptive use (mm) } \\
\hline \multirow{4}{*}{$\begin{array}{c}1.25 \\
1.00 \\
0.75 \\
\text { Mean }\end{array}$} & 317 & 359 & 383 & 353 & 302 & 346 & 423 & 357 \\
\hline & 300 & 313 & 336 & 316 & 275 & 315 & 368 & 319 \\
\hline & 245 & 268 & 278 & 264 & 265 & 279 & 300 & 281 \\
\hline & 287 & 313 & 332 & 309 & 281 & 313 & 364 & 319 \\
\hline
\end{tabular}

With respect to nitrogen fertilizer levels, seasonal ETa values were 287, 313 and $332 \mathrm{~mm}$ for $N_{1}(60 \mathrm{~kg} \mathrm{~N} / \mathrm{fed}), N_{2}(75 \mathrm{~kg} \mathrm{~N} / \mathrm{fed})$ and $N_{3}(90 \mathrm{~kg}$ $\mathrm{N} / \mathrm{fed}$ ), respectively, for the first season However in the second season, values were 281, 313 and $364 \mathrm{~mm}$ for the same $\mathrm{N}$-level treatments. These results indicate that ETa values increased with increasing $\mathrm{N}$ - levels. The increased values of ETa with the highest level of $N\left(N_{3}\right)$ were 13.65 and $22.80 \%$ for first and second season, respectively as compared with the lowest level of $N\left(N_{1}\right)$. These results are in a good agreement with those obtained by Sidrak (2003) who reported that seasonal water use generally increased with increasing $\mathrm{N}$ rate.

\section{1- 2-Water Use Efficiency (WUE):}

Values of water use efficiency as recorded in Table (5) indicate that irrigation at 1.00 evaporation pan coefficient gave the maximum water use efficiency of $7.56 \mathrm{~kg}$ grains $/ \mathrm{mm}$ water in 2005/2006 season, while the minimum value was7.23 $\mathrm{kg}$ grains $/ \mathrm{mm}$ water was recorded at $1.25 \mathrm{EPC}$ treatment. In 2006/2007 season the maximum value was $8.03 \mathrm{~kg}$ grains $/ \mathrm{mm}$ resulted from $1.00 \mathrm{EPC}$ treatment, whereas the minimum value was $7.37 \mathrm{~kg}$ grains $/ \mathrm{mm}$ obtained with 1.25 EPC treatment. The two-season results indicate that WUE increased with medium number of irrigation during growing season according to irrigating at medium level of evaporation pan coefficient. These results are in harmony with those reported by EL-Marsafawy (2000) who found that the highest WUE value for wheat was achieved as irrigation practiced according to 1.0 EPC.

Results in Table (5) indicate that the highest value of water use efficiency, 7.80 and $8.00-\mathrm{kg}$ grain $/ \mathrm{mm} / \mathrm{fed}$, was obtained with applying $75 \mathrm{~kg}$ $\mathrm{N} /$ fed (N2) for both growing seasons. However the lowest one (7.30 and 7.40 $-\mathrm{kg}$ grain $/ \mathrm{mm} / \mathrm{fed}$ ), was obtained with applying $60 \mathrm{~kg} \mathrm{~N} /$ fed N1. It is clear that both season results reveal that applying $75 \mathrm{~kg} \mathrm{~N} /$ fed (recommended level) increased WUE to a maximum value compared to $90 \mathrm{~kg} \mathrm{~N} / \mathrm{fed}$ (low level) and then declined with increasing $\mathrm{N}$ - level up to $90 \mathrm{~N} / \mathrm{fed}$. It could be stated that the most effective level of $\mathrm{N}$ - fertilizer application with wheat cultivar under study is $75 \mathrm{~kg} \mathrm{~N} / \mathrm{fed}$ (recommended level) at Giza region. This may be due to that $\mathrm{N}$-fertilizer is subjected to be lost by leaching at high levels. In this connection, Ghulam and Al- Jaloud (1995) reported that WUE for winter wheat was increased with increasing $\mathrm{N}$ - application. 
Table (5): Water use efficiency ( $\mathrm{kg}$ grain $/ \mathrm{mm} / \mathrm{fed}$ ) of wheat cultivar Sakha69 as affected by irrigation regime and $\mathbf{N}$ fertilizer levels at Giza region in $2005 / 2006$ and 2006/2007 seasons.

\begin{tabular}{|c|c|c|c|c|c|c|c|c|}
\hline Season & \multicolumn{4}{|c|}{$2005 / 2006$} & \multicolumn{4}{|c|}{$2006 / 2007$} \\
\hline Irrigation & \multicolumn{8}{|c|}{$\mathrm{N}$ - levels ( $\mathrm{kg} / \mathrm{fed})$} \\
\hline Regime & 60 & 75 & 90 & Mean & 60 & 75 & 90 & Mean \\
\hline \multicolumn{9}{|c|}{ Water use efficiency (kg grains $/ \mathrm{mm}$ water } \\
\hline 1.25 & 6.95 & 7.38 & 7.32 & 7.23 & 6.99 & 7.73 & 7.10 & 7.37 \\
\hline 1.00 & 7.37 & 7.46 & 7.41 & 7.56 & 8.4 & 8.31 & 7.39 & 8.03 \\
\hline 0.75 & 6.91 & 7.94 & 7.66 & 7.51 & 7.28 & 8.11 & 7.85 & 7.75 \\
\hline Mean & 7.50 & 7.80 & 7.30 & 7.50 & 7.80 & 8.00 & 7.40 & 7.72 \\
\hline
\end{tabular}

\subsection{Potential evapotranspiration ETo:}

Potential evapotranspiration (ETo) throughout wheat growing season duration was estimated from the climatic data of Giza region by Modified Penman, Penman Monteih and Doorenbos - Pruitt. The wheat crop coefficient (Kc) (FAO, 2002), wheat crop evapotranspiration (ETc) values were calculated as follows:

$$
\mathrm{Etc}=\mathrm{Kc}{ }^{*} \text { Eto. }
$$

Generally, results shown in Table 6 indicate that there were small differences between calculated ETc for the two seasons. This may be due to the variation in the weather conditions. In 2005/2006, seasonal estimated ETc values were $325.0,351.0$ and 403.0, mm for the Modified Penman, Penman Monteih and Doorenbos - Purist, respectively. However the corresponding values were $339.0,354.0$ and $421.0 \mathrm{~mm}$ for the same respective formulas in 2005-2006 season.

It is clear that estimated ET varied for the three used formulas and the Doorenbos - Pruitt formula gave the maximum ET crop values in both seasons as compared with others. On the other hand, monthly ETc values of the three formulas started small according to the small plants cover in the early stage, then increased to reach their maximum values in mid season (March) as a result of a complete crop canopy with highest value of crop coefficient $(\mathrm{Kc})$ addition to increase in weather factors value (i.e. temperature, solar radiation and pan evaporation) which calculated formulas are based on, and then tended to decline again until the crop maturity (May) lower Kc. These results may be due to the differences in climatic factors on which calculated formulas are based on. In this concern, Chang (1971) reported that the rate of ETO depended on evaporation power of the temperature, wind speed, relative humidity and solar radiation. The obtained results are in harmony with those obtained by Sidrak (2003). 
Poraas, M. M. E. et al.

6 


\section{1-4. Comparison of ET crop with the actual ET:}

Results of the three mentioned methods and their efficiency in calculating ET crop as compared with actual ET (to select the best one at Giza region for wheat crop under study) are shown in Table 7.

Results of 2005/2006 season reveal that ratios between ET crop and actual ET were 1.03, 1.11 and 1.28 for Modified Penman, Penman Monteith and Doorenbos-Pruitt, respectively. However, in 2006/2007 season, the recorded values were $1.05,1.10$ and 1.30 for the same respective formulas. The overall averages in both seasons were 1.04, 1.10 and 1.29 for the same respective formulas. Results of both seasons reveal that the Modified Penman was the most efficient and relevant in calculating ET crop for wheat in Middle Egypt (.i.e., Giza region) as compared with other methods. It is noticed also that the Doorenbos -Pruitt method recorded unsuitable ratio. These results may be due to differences in weather parameter on which each formula is based on for calculating ETo.

Table (7): Comparison between the actual (ETa) and estimated (ETc) for wheat plants grown at Giza region in 2005/2006 and 2006/2007 seasons

\begin{tabular}{|l|c|c|c|c|c|c|}
\hline \multicolumn{2}{|c|}{ Season } & \multicolumn{2}{|c|}{$\mathbf{2 0 0 5 / 2 0 0 6}$} & \multicolumn{2}{c|}{$\mathbf{2 0 0 6 / 2 0 0 7}$} & \multicolumn{2}{c|}{ Average } \\
\hline Estimated (ETc) & ET & Ratio & ET & Ratio & ET & Ratio \\
\hline Modified Penman & 325 & 1,03 & 339 & 1,05 & 332 & 1,04 \\
\hline Penman Monteith & 351 & 1,11 & 354 & 1,10 & 353 & 1,10 \\
\hline Doorenbos-Pruitt & 403 & 1,28 & 421 & 1,30 & 412 & 1,29 \\
\hline Actual (Eta) & 316 & & 323 & & 320 & \\
\hline
\end{tabular}

2- Growth, yield and some yield attributes:

\section{2-1. Plant height:}

Data in Table (8) reveal that significant effect was found on plant height due to irrigation regime in both seasons of study. The longest plants $(89.0 \mathrm{~cm}$ in season1and $95.0 \mathrm{~cm}$ in season 2), respectively, was obtained under irrigating according to 1.25 pan evaporation coefficient (EPC), while the shortest plants, 77.0 and $80.0 \mathrm{~cm}$ were resulted from irrigating at $0.75 \mathrm{EPC}$ treatment, and this was true in the both studied seasons. These results are in agreement with those of Ali (1997) and Hefnawy and Wahba (2003).Data also show that, there are significant differences among nitrogen levels to influence plant height trait in both seasons. The highest values of 87.0 (season1) and 88.0-cm (season2) were obtained with applying $90 \mathrm{~kg} / \mathrm{N} / \mathrm{fed}$ (N3), while the lowest values of 72.0 and $76.0 \mathrm{~cm}$ were recorded with N1 treatment. Average plant height was significantly increased by 17.24 and $13.66 \%$ with N3 as compared with N1 for both seasons, respectively. This effect of $\mathrm{N}$ may be due to its role in development and elongation of roots thus using water more efficiently. These results are in harmony with those obtained by Sidrak (2003) who found that plant height increased with increasing $\mathrm{N}$ - fertilizer application for wheat crop from 50 up to $100 \mathrm{~kg} \mathrm{~N} / \mathrm{fed}$. The interaction between irrigation regimes and nitrogen levels was significant to alter such trait in both seasons, and the tallest plants were obtained form irrigation by according to 1.25 EPC combined with $90 \mathrm{~kg} / \mathrm{N} / \mathrm{fed}$ (N3). 


\section{2-2. Grain weight /spike:}

The average values of grain weight /spike as recorded in Table (8) indicate that increasing EPC value caused a significant increase in grain weight/ spike. The highest average values of 2.6 (season1) and $2.9 \mathrm{~g}$ (season 2) were obtained when plants received irrigation at 1.25 EPC, and the lowest average values of 1.8 and $2.0 \mathrm{~g}$ for each season was obtained at 0.75 EPC. This trend may be due to more available soil moisture under high level of EPC (1.25) resulting in increasing water and nutrients uptake and hence enhancing grain weight /spike. These results are in agreement with those obtained by El-Sabbagh et al. (2002) and Moussa and Abdel-Maksoud (2004). Regarding N- fertilizer, results show a positive significant effect on grain weight /spike. The highest values of $2.4 \mathrm{~g}$ (season1) and $2.8 \mathrm{~g}$ (season2) were obtained with applying $90 \mathrm{~kg} \mathrm{~N} / \mathrm{fed}$ (N3), while the lowest accompanied adding N1 treatment with values of $2.0 \mathrm{~g}$ (season1) and $2.2 \mathrm{~g}$ (season 2). Averages of grain weight/spike were increased by 16.7 and 21.48 $\%$ with N3 as compared with N1 in first and second season, respectively. These results are in agreement with those obtained by Pandey et al. (2001).

Table (8): Plant height (cm), grain weight./spike (g) and 1000-grain weight $(\mathrm{g})$ of wheat crop as affected by irrigation regime and $\mathrm{N}$ fertilizer levels at Giza region in 2005 /2006 and 2006/2007 seasons

\begin{tabular}{|c|c|c|c|c|c|c|c|c|c|c|}
\hline \multirow{2}{*}{\begin{tabular}{|c|} 
Irrigation \\
regime
\end{tabular}} & \multirow{2}{*}{$\begin{array}{c}\mathrm{N} \text { - fertilizer } \\
\text { level }\end{array}$} & \multicolumn{3}{|c|}{ Plant height (cm) } & \multicolumn{3}{|c|}{ Grain weigh /spike(g) } & \multicolumn{3}{|c|}{ 1000-grain weight (g) } \\
\hline & & $\begin{array}{l}2005 \\
/ 2006\end{array}$ & $\begin{array}{l}2006 \\
/ 2007\end{array}$ & Average & $\begin{array}{l}2005 \\
/ 2006\end{array}$ & $\begin{array}{l}2006 \\
/ 2007\end{array}$ & Average & $\begin{array}{l}2005 \\
/ 2006\end{array}$ & $\begin{array}{l}2006 \\
/ 2007\end{array}$ & Average \\
\hline \multirow{4}{*}{1.25} & $60 \mathrm{~kg} / \mathrm{fed}$ & 84.0 & 88.0 & 86.0 & 2.4 & 2.5 & 2.5 & 43.8 & 47.0 & 45.4 \\
\hline & $75 \mathrm{~kg} / \mathrm{fed}$ & 90.0 & 96.0 & 93.0 & 2.6 & 3.0 & 2.8 & 46.3 & 49.8 & 48.1 \\
\hline & $90 \mathrm{~kg} / \mathrm{fed}$ & 93.0 & 99.0 & 96.0 & 2.9 & 3.3 & 3.1 & 47.0 & 52.1 & 49.6 \\
\hline & Average & 89.0 & 95.0 & 92.0 & 2.6 & 2.9 & 2.8 & 45.7 & 49.6 & 47.7 \\
\hline \multirow{4}{*}{1.00} & $60 \mathrm{~kg} / \mathrm{fed}$ & 80.0 & 81.0 & 80.5 & 2.1 & 2.3 & 2.2 & 42.6 & 45.4 & 44.0 \\
\hline & $75 \mathrm{~kg} / \mathrm{fed}$ & 83.0 & 85.0 & 84.0 & 2.4 & 2.8 & 2.6 & 43.5 & 47.0 & 45.3 \\
\hline & $90 \mathrm{~kg} / \mathrm{fed}$ & 86.0 & 89.0 & 87.5 & 2.4 & 2.9 & 2.7 & 45.9 & 47.8 & 46.9 \\
\hline & Average & 83.0 & 85.0 & 84.0 & 2.3 & 2.7 & 2.5 & 44.0 & 46.7 & 45.4 \\
\hline \multirow{4}{*}{0.75} & $60 \mathrm{~kg} / \mathrm{fed}$ & 72.0 & 76.0 & 74.0 & 1.6 & 1.9 & 1.8 & 35.5 & 37.6 & 36.6 \\
\hline & $75 \mathrm{~kg} / \mathrm{fed}$ & 79.0 & 81.0 & 80.0 & 1.8 & 2.1 & 2.0 & 37.7 & 40.6 & 39.2 \\
\hline & $90 \mathrm{~kg} / \mathrm{fed}$ & 81.0 & 83.0 & 82.0 & 2.0 & 2.3 & 2.2 & 39.6 & 42.4 & 41.0 \\
\hline & Average & 77.0 & 80.0 & 78.5 & 1.8 & 2.1 & 2.0 & 37.6 & 40.2 & 38.9 \\
\hline \multicolumn{2}{|c|}{ Average $60 \mathrm{~kg} / \mathrm{fed}$} & 79.0 & 82.0 & 80.5 & 2.0 & 2.2 & 2.1 & 40.6 & 43.3 & 42.0 \\
\hline \multicolumn{2}{|c|}{ Average $75 \mathrm{~kg} / \mathrm{fed}$} & 84.0 & 85.0 & 84.5 & 2.3 & 2.6 & 2.5 & 42.5 & 45.3 & 43.9 \\
\hline \multicolumn{2}{|c|}{ Average $90 \mathrm{~kg} / \mathrm{fed}$} & 87.0 & 88.0 & 87.5 & 2.4 & 2.8 & 2.6 & 44.2 & 47.4 & 45.8 \\
\hline \multicolumn{11}{|c|}{ L.S.D. at $5 \%$} \\
\hline \multirow{3}{*}{ 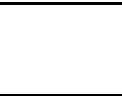 } & irrigation & 1.25 & 5.40 & & 0.15 & 0.27 & & 0.93 & 0.97 & \\
\hline & $\mathrm{N}$ - levels & 0.88 & 4.33 & & 0.11 & 0.16 & & 1.07 & 1.03 & \\
\hline & Interaction & N.S. & N.S. & & N.S. & N.S. & & N.S. & N.S. & \\
\hline
\end{tabular}

\section{2-3. The 1000-grain weight:}

As shown in Table (8) the 1000-grain weight was influenced significantly by the irrigation regimes in the two studied seasons. The highest values of $45.7 \mathrm{-g}$ (season1) and 49.6 (season2) resulted under irrigation at 1.25 EPC. Comparable values for 1.00 EPC are 44.0 and 46.7 and 37.6 and $40.2 \mathrm{~g}$ for $0.75 \mathrm{EPC}$ in season 1 and season2, respectively. These results are in agreement with those obtained by El-Kalla et al. (1995) and Moussa and Abdel-Maksoud (2004) who reported that 1000-grain weight tended to 
decrease as soil moisture availability decreased.The differences in the values of 1000-grain weight among the nitrogen levels were significant in both growing seasons. The highest values of 44.2 (season1) and $47.4 \mathrm{~g}$ (season2) were obtained with adding $90 \mathrm{~kg} \mathrm{~N} / \mathrm{fed}$, while the lowest ones of 40.6 and 43.3 were recorded in season 1 and season2, respectively with applying $60 \mathrm{~kg} \mathrm{~N} / \mathrm{fed}$. Results reveal that increasing nitrogen levels significantly increased the 1000-grain weight values. These results are in harmony with those obtained by Sidrak (2003) who noticed that grain yield components were affected by increasing $N$ rate from 50 to $100 \mathrm{~kg} \mathrm{~N} /$ fed. No significant interaction effect was found in both seasons. The maximum values, 47.0 and $52.1 \mathrm{~g}$ were obtained from the treatment of $1.25 \mathrm{EPC}+90$ $\mathrm{kg} \mathrm{N} / \mathrm{fed}$ in the first and second growing season, respectively. The lowest values of 35.5 and $37.6 \mathrm{~g}$ were obtained from the treatment of $0.75 \mathrm{EPC}+$ $60 \mathrm{~kg} \mathrm{~N} / \mathrm{fed}$ for the same respective seasons.

\section{2-4. Number of spike/ $\mathrm{m}^{2}$ :}

Data in Table (9) show that the adopted irrigation treatments significantly affected the number of spike $/ \mathrm{m}^{2}$ in both seasons. The highest values were 304.0 and $330 \mathrm{spike} / \mathrm{m}^{2}$ obtained from irrigation at 1.00 evaporation pan coefficient in the first and second season, respectively. However, the lowest values were 237.0 and $271 \mathrm{spike} / \mathrm{m}^{2}$ obtained from irrigation at $0.75 \mathrm{EPC}$ for the same respective seasons. In respect to both season results, it could be concluded that frequent irrigation caused an increase in number of spike/m2. This might be attributed to positive effect of moderate available moisture at grain filling which increase the starch content and organic compounds in wheat plants. These results agree with those obtained by Rayan et al. (2000), Sidrak (2003) and Salem et al. (2006). Data also indicate that number of spike/m2was significantly and regularly increased with increasing nitrogen levels. The highest values of 296.0 (season1) and 317.0 spike $/ \mathrm{m}^{2}$ (season2) were obtained with applying N3 treatment, while lowest values of 264.0 (season1) and $298.0 \mathrm{spike} / \mathrm{m}^{2}$ (season2) were found with $\mathrm{N} 1$ treatment. Average number of spike $/ \mathrm{m}^{2}$ was increased by 10.8 and $5.6 \%$ with addition of $90 \mathrm{~kg} \mathrm{~N} /$ fed (N3) as compared with $60 \mathrm{~kg} \mathrm{~N} / \mathrm{fed}(\mathrm{N} 1)$ for both growing seasons. These results agree with those obtained by Bing and Sheng (2006). The interaction results reveal that none- significant effect was found between different treatments. The maximum values of $318.0 \mathrm{spike} / \mathrm{m}^{2}$ and $336 \mathrm{spike} / \mathrm{m}^{2}$ were obtained by 1.25 and $1.00 \mathrm{EPC}+90 \mathrm{~kg} \mathrm{~N} /$ fed for (season 1) and (season2), respectively, while the lowest values of $215.0 \mathrm{spike} / \mathrm{m}^{2}$ (season 1) and $260.0 \mathrm{spike} / \mathrm{m}^{2}$ (season2) were gained by $0.75 \mathrm{EPC}+60 \mathrm{~kg} \mathrm{~N} / \mathrm{fed}$.

\section{2-5. Straw yield:}

Data in Table (9) show that irrigation treatments significantly affected straw yield in both seasons. The highest values of $5952 \mathrm{~kg} / \mathrm{fed}$ (season1) and $6125 \mathrm{~kg} / \mathrm{fed}$ (season 2) were obtained from irrigating at $1.25 \mathrm{EPC}$ treatment, then tended to decrease as irrigation was scheduled at 1.00 and 0.75 EPC. Increases due to 1.25 over 0.75 EPC were 31.7 and $35.4 \%$ for the same respective seasons. This reflects the effect on growth attributes and number of productive tillers. These finding are similar to those obtained by Laura et al. (2008). Regarding the effect of nitrogen fertilizer levels, results show a 
significant effect on straw yield with average values of 4884, 5265, and 5497 for N1, N2 and N3, respectively for the first season. Comparable average values for the second season are 5366, 5604, and 6131 for the same respective treatments. The average increases for straw yields of N3 over the yield of N1for both seasons were 11.15 and $12.48 \%$, respectively. These results are in full agreement with those reported by Sidrak (2003) who found that increasing $\mathrm{N}$ level up to $100 \mathrm{~kg} \mathrm{~N} / \mathrm{fed}$ increased straw yield of wheat crop. There was significant interaction between irrigation regime and $\mathrm{N}$ level; the interaction is shown when the decrease occurred with the decreases in EPC, which was particularly considerable under high $\mathrm{N}$ levels.

Table (9): Number of spike $/ \mathrm{m}^{2}$, straw and grain yield $(\mathrm{kg} / \mathrm{fed})$ of wheat crop as affected by irrigation regime and $\mathrm{N}$ fertilizer levels at Giza region in $2005 / 2006$ and $2006 / 2007$ seasons

\begin{tabular}{|c|c|c|c|c|c|c|c|c|c|c|}
\hline \multirow{2}{*}{$\begin{array}{c}\text { Irrigation } \\
\text { regime }\end{array}$} & \multirow{2}{*}{$\begin{array}{c}\mathrm{N} \text {-fertilizer } \\
\text { level }\end{array}$} & \multicolumn{3}{|c|}{ Number of spike $/ \mathrm{m}^{2}$} & \multicolumn{3}{|c|}{ grain yield (kg /fed) } & \multicolumn{3}{|c|}{ straw yield (kg /fed)) } \\
\hline & & \begin{tabular}{|l|}
2005 \\
$/ 2006$ \\
\end{tabular} & \begin{tabular}{|l|}
2006 \\
$/ 2007$
\end{tabular} & Average & $\begin{array}{l}2005 \\
/ 2006\end{array}$ & \begin{tabular}{|l|}
2006 \\
$/ 2007$
\end{tabular} & Average & \begin{tabular}{|l|}
2005 \\
$/ 2006$ \\
\end{tabular} & $\begin{array}{l}2006 \\
/ 2007\end{array}$ & Average \\
\hline \multirow[t]{4}{*}{1.25} & $60 \mathrm{~kg} / \mathrm{fed}$ & 286.0 & 314.0 & 300.0 & 2202 & 2111 & 2157 & 5471 & 5876 & 5674 \\
\hline & $75 \mathrm{~kg} / \mathrm{fed}$ & 305.0 & 326.0 & 315.5 & 2648 & 2699 & 2674 & 5936 & 6133 & 6035 \\
\hline & $90 \mathrm{~kg} / \mathrm{fed}$ & 318.0 & 334.0 & 326.0 & 2805 & 2825 & 2815 & 6299 & 6456 & 6378 \\
\hline & Average & 303.0 & 325.0 & 311.5 & 2552 & 2545 & 2549 & 5952 & 6125 & 6039 \\
\hline \multirow[t]{4}{*}{1.00} & $60 \mathrm{~kg} / \mathrm{fed}$ & 290.0 & 320.0 & 305.0 & 2210 & 2134 & 2172 & 5063 & 5700 & 5382 \\
\hline & $75 \mathrm{~kg} / \mathrm{fed}$ & 308.0 & 334.0 & 321.0 & 2335 & 2402 & 2369 & 5414 & 5908 & 5661 \\
\hline & $90 \mathrm{~kg} / \mathrm{fed}$ & 314.0 & 336.0 & 325.0 & 2489 & 2483 & 2486 & 5576 & 6632 & 6104 \\
\hline & Average & 304.0 & 330.0 & 317.0 & 2345 & 2340 & 2343 & 5321 & 6080 & 5701 \\
\hline \multirow[t]{4}{*}{0.75} & $60 \mathrm{~kg} / \mathrm{fed}$ & 215.0 & 260.0 & 237.5 & 1832 & 1900 & 1866 & 4118 & 4522 & 4320 \\
\hline & $75 \mathrm{~kg} / \mathrm{fed}$ & 240.0 & 273.0 & 256.5 & 2129 & 2156 & 2143 & 4435 & 4771 & 4603 \\
\hline & $90 \mathrm{~kg} / \mathrm{fed}$ & 256.0 & 280.0 & 268.0 & 2129 & 2285 & 2207 & 4617 & 5305 & 4961 \\
\hline & Average & 237.0 & 271.0 & 254.0 & 2030 & 2114 & 2072 & 4390 & 4866 & 4628 \\
\hline \multicolumn{2}{|c|}{ Average $60 \mathrm{~kg} / \mathrm{fed}$} & 264.0 & 298.0 & 281.0 & 2421 & 2419 & 2420 & 4884 & 5366 & 5125 \\
\hline \multicolumn{2}{|c|}{ Average $75 \mathrm{~kg} / \mathrm{fed}$} & 284.0 & 311.0 & 297.5 & 2491 & 2531 & 2511 & 5265 & 5604 & 5435 \\
\hline \multicolumn{2}{|c|}{ Average $90 \mathrm{~kg} / \mathrm{fed}$} & 296.0 & 317.0 & 306.5 & 2342 & 2333 & 2338 & 5497 & 6131 & 5814 \\
\hline \multirow[t]{3}{*}{ L.S.D.at 5\% } & \% Irrigation & 6.19 & 13.58 & & 85.9 & 88.38 & & 146.88 & 71.75 & \\
\hline & $\mathrm{N}$ - levels & 6.19 & 9.37 & & 66.21 & 49.22 & & 108.80 & 54.97 & \\
\hline & Interac. & N. S. & N. S. & & N.S. & N. S. & & 188.44 & 95.21 & \\
\hline
\end{tabular}

2-6. Grain yield $(\mathrm{kg} / \mathrm{fed})$ :

Results in Table (9) show that the grain yield was significantly influenced due to irrigation regimes in the both growing seasons. Wheat grain yield was higher as the plants were irrigated at 1.25 EPC, which reached to 8.83 and $9.58 \%$ for EPC 1.25 treatment over the 1.00 and 0.75 EPC treatments in increases to the first season. In the second season the 1.25 EPC surpassed the 0.75 EPC by $20.39 \%$. The superiority of the $1.25 \mathrm{EPC}$ shows that sufficient irrigation increased grain yield of wheat crop. This trend reflects the importance of soil water to increase plant nutrient availability in soil solution and to improve all growth factor and yield components, which lead to increases production of wheat grain yield. On other hand, results may prove that water stress is one of the main environmental factors, which negatively affects yield production by increasing water pressure around plant roots and due to reduction of water and nutrient uptake. These results are in harmony with those obtained by Amin (2003) and Metin Sezen et al. (2006) who stated that wheat crop in the arid region for three growing season 
showed highest average grain yields at the highest irrigation level. Nitrogen level had a significant effect on grain yield as shown in Table 9. Average value was higher as the plants were treated by $75 \mathrm{~kg} \mathrm{~N} / \mathrm{fed}$ with small increase of 2.81 and $3.62 \%$ over $60 \mathrm{~kg} \mathrm{~N} / \mathrm{fed}$ treatment for season1 and season2. This may be attributed to the utilization of nitrogen at recommended rate for this cultivar. These results are in agreement with those obtained by Awad et al. (2000) and lqbal et al. (2005) who noticed that applying $60 \mathrm{~kg} \mathrm{~N}$ ha-1 increased grain yield for wheat grown under semi-arid conditions as compared with $30 \mathrm{~kg} \mathrm{~N}$ ha- ${ }^{1}$. No significant interaction effect was found in the current study between irrigation regime and nitrogen fertilizer levels in both growing seasons.

In conclusion, under Giza area conditions, it is advisable to use Sakha69 wheat cultivar with irrigation according to $1.00 \mathrm{EPC}$ and treated with $75 \mathrm{~kg} \mathrm{~N} /$ fed since most of growth, yield and yield components traits and water use efficiency were enhanced with such treatments.

\section{REFERENCES}

Abdel Ghani, A. M., A . A . Gomaa, A .M. Abdel Shafi, Enayat H. Ghanem, O. S. Khalil, R. A. Abo Elenein and A. M. Essa (1994). Differential development of wheat production in Egypt out of recognition yield transformation. Assiut J. Agric. Sci., 25 ( 21 ) :39-58.

Abou-Ahmed, E. L. (1999). Effect of water stress and nitrogen fertilization on wheat production. J. Agric. Sci. Mansoura Univ., 24(8):4327-4337.

Abu-Zeid, M. (1999). Egypt's Water Policy for the $21^{\text {st }}$ Century, $7^{\text {th }}$ Nile 2002 Conference, March 15-19, 1999, Cairo, Egypt.

Ali, S. A. (1997). Effect of some agricultural practices on growth., yield and yield components of wheat. Ph.D.Thesis, Fac. Agric., El-Menia Univ., Egypt.

Amin, I. A. (2003). Selection for drought tolerance in wheat, Ph.D Thesis, Fac . of Agric, El-Menia University.

Angus, J. F. and A. F. Van -Herwaarden (2001). Increasing Water Use and Water Use Efficiency in Dryland Wheat. Agronomy J., (93): 290-298.

Awad, H. A., H. E. Khalifa and M. H. El-khouli (2000). Influence of nitrogen fertilizer levels and water deficit during some growth stages on wheat yield at the North Delta of Egypt. J. Agric. Sci. Mansoura Univ., 25(7): 4727-4735.

Bing-nian, Z. and L. I. Sheng-xiu (2006). Study on the Key and Sensitive Stage of Winter Wheat Responses to Water and Nitrogen Coordination. Agricultural Sciences in China. 5(1):50-56.

Chang, J. H. (1971). "Climate and Agriculture" An ecological survey. Aldine publishing company Chicago. USA.

Eid, H. M.; N. G. Ainer, S. M. El-Marsafawy and A.N. Khater (1999).Crop water needs under different irrigation systems in the new lands. Third Conf.of On-Farm Irrigation and Agrocilmatology. Soils, Water and Environ. Res. Inst., ARC, Ministry of Agric. and Land Reclamation, Egypt. Jauary 25-27.1999. 
El-Kalla, S. E. A. E.; A. A. Leilah , A. H. Basiony and S. M. Hussein (1995). Effect of irrigation and foliar nutrition treatments on growth and yield of some wheat cultivars under Al-Arish area conditions. Proc. $6^{\text {th }}$ Conf. Agron., Al-Azhar Univ., Cairo 1:362-378 .

El-Marsafay, S. M. (2000). Scheduling irrigation of wheat crop under different phosphorus fertilizer application times in Middle Egypt . Proc. 5th Conference - Meteorology \& Sustainable Development: 182-195.

El- Sabbagh, A. A., S. A. Abd El- Hafez, A. Z. El-Bably and E. I. Abou-Ahmed .2002. Response of wheat crop to irrigation intervals and foliar application of potassium. J . agric. Res. Tanta Univ., 28 (2):525-538.

El-Shaer, M. H., C. Rosenzweig, A. Iglesias H. M. Eid and D. Hellil (1997). Impact of climate change on possible scenarios for Egyptian agriculture in the future. Mitigation and Adaptation Strategies for Global Change.1: 233-250.

El-Yamany, M. S. (1994). Study on the effect of some fertilizer treatments on wheat under different irrigation conditions Ph.D. Thesis, Kafr El-Sheikh, Tanta Univ., Egypt.

FAO. 1980. Yield response to water by Doorenbos, J. and A. Kassam. FAO Irrigation and Drainage Paper No. 33, Rome, Italy.

FAO. 2002. Deficit irrigation practices. FAO Water Reports No. 56, Rome, Italy.

Fischer, R. A., F. Santiveri and I. R. Vidal (2002).Crop rotation, tillage and crop residue management for wheat and maize in the sub-humid tropical highlands. Field Crops Research.79 (2-3): 123-137.

Ghulam, H. and A. Al-Joloud (1995). Effect of irrigation and nitrogen on water use efficiency of wheat in Soudi Arabi.. Agricultural Water Management, 27:143-153.

Hefnawy, F.A. and M. F. Wahba (2003). Effect of water stress in late growth stages of some wheat cultivars. J. Agric. Sci. Mansoura Univ., 28(2): 729-745.

Iqbal , M. M., J. Akhter, W. Mohammad, S. M. Shah, H. Nawaz, K. Mahmood (2005). Effect of tillage and fertilizer levels on wheat yield, nitrogen uptake and their correlation with carbon isotope discrimination under rainfed conditions in north-west Pakistan .Soil and Tillage Research. 80(1-2): 47-57.

Israelsen, O. W. and V. E. Hansen (1962). Irrigation principles and practices $.3^{\mathrm{d}} \mathrm{ed}$., John Wiley and Sons Inc., New York .USA.

Jensen, M. C. and J. E. Middleton (1965). Scheduling irrigation from pan evaporation. WashingtonAgric.Exp.Station,Collageof Agric.,Washington State Univ., Circular 386, revised 1965.

Jones, J. W.; L. H. Allen; S. F. Shih; J. S. Rogers; L. C. Hammond, A. G. Smajstrala and J. D. Martolf (1984).Estimatedand measured evapotranspiration for Florida climate, crop and soils agricultural experiment stations. Institute of Food and Agricultural Sciences, Univ. Florida.

Khalii, F. A. F., G. A. El-Shaarawy and H. Y. M. Hasan (2005). Irrigation scheduling for some wheat cultivars through pan evaporation norms and its effect on growth, yield and water use efficiency Fayoum J. Agric. Res. \& develop., 21(1):1-15. 
Laura E., L. Lulli, M. Mariotti, A. Masoni and I. Arduini (2008). Post-anthesis dry matter and nitrogen dynamics in durum wheat as affected by nitrogen supply and soil water availability. Eur. J. Agron., 28 (2): 138147.

Lewandowski, I. and D. Kauter (2003). The influence of nitrogen fertilizer on the yield and combustion quality of whole grain crops for solid fuel us Industrial Crops and Products. 17 (2):103-117.

Metin, S. and Y. Attila- (2006). Wheat yield response to line-source sprinkler irrigation in the arid Southeast Anatolia region of Turkey. Agric. Water Management. 81 (1-2): 59-76.

Mohamed. K. A; and A. M. Tammam (1999). Drought resistance of some wheat varieties in Upper Egypt. Third Conf .On - Farm Irri \& Agroclimtology, SWERI, ARC, Egypt .1(2): 623-632.

Moussa , A. M. and H. H. Abdel-Maksoud (2004). Effect of soil moisture regime on yield and its components and water use efficiency for some wheat cultivars. Annals Agric. Sci., Ain Shams Univ., 49 (2):515-530.

Pandey, R. K., J. W. Maranville and A. Admou (2001).Tropical wheat response to irrigation and nitrogen in a Sahelian environment. Grain yield, yield components and water use efficiency, Eur. J. Agron., 15( 2): 93-105.

Rayan, A. A.; S. M. El-Marsafawy and K. A. Mohamed (1999). Response of wheat varieties to different sowing dates and irrigation regimes in Upper Egypt . 3rd Conf. on Farm Irrigation and Agroclimatology, Giza, Paper No. 44.

Rayan, A. A., S. M. El-Marsafawy , N. G. Ainer and S.E. Soliman (2000). Schedule irrigation of wheat crop in Upper Egypt under some sowing dates. Egypt. J. Appl. Sci ., 15 (1) : 10-23 .

Salem, N. R. A., G. A. El-Shaarwy and H. H. Abdel-Maksoud (2006). Performance of two bread wheat cultivars under different irrigation regimes. Egypt. J. Appl. Sci., 21(12): 60-82.

Sendecor, W. G. and W. G. Cochran (1980). Statistical methods. $6^{\text {th }}$ edition, Oxford and J.B.H. publishing Co.

Shahin, M. M. and E. M. Mosa (1994). Irrigation cycles in relation to yield and water relation for wheat. Annals Agric.Sci., Moshtohor, 32(1):35-49.

Sidrak, N. N. (2003). Scheduling irrigation of wheat using the evaporation pan method under different times and rates of nitrogen fertilizer."M. Sc. Thesis, Fac. Agric. Zagazig Univ., Egypt.

Singh, P. N., G. Singh and P. Dey (1996). Effect of supplemental irrigation and nitrogen application wheat on water use, yield and uptake of major nutrients Jjournal of the Indian Society of Soil Science 44(2): 189-201.

Vites, F.G.Jr .1965. Increasing water use efficiency by soil management. Amer. Soc. Agron., Madison, Wisc. USA. Pp. 259-274.

Wenlong, Li., Li. Weide and Li. Zizhen (2004). Irrigation and fertilizer effects on water use and yield of spring wheat in semi-arid regions. Agric. Water Manag., 67: 35-46

Zazueta, F. S. and A. G. Smajstrla (1984). Evapotranspiration estimation utilities (WATER) model. Agricultural Engineering Department, IFAS, Univ. Florida, Gainesville, Florida, USA. 
Poraas, M. M. E. et al.

تأثير جدولة الري ومعدلات مختلفة من التسميد النيتروجيني على العلاقات المائية

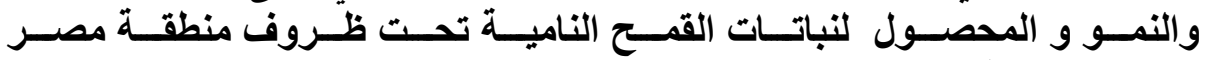
الوسطي(منطقة الجيزة)

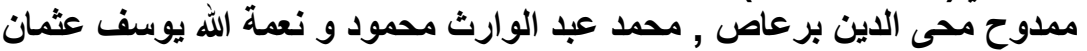

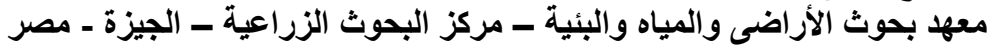

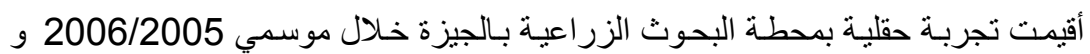

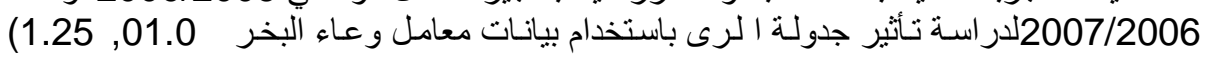

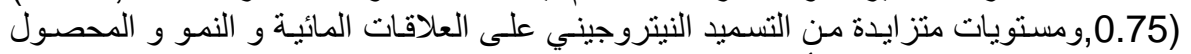

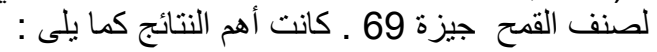

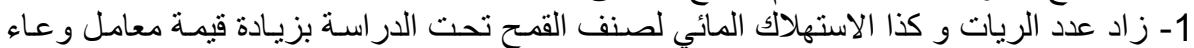

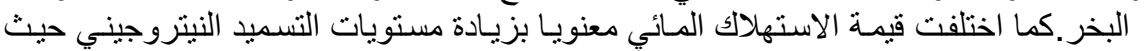

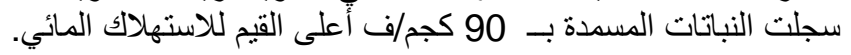

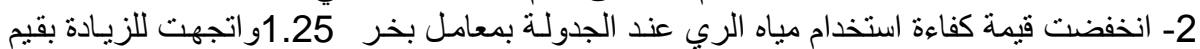

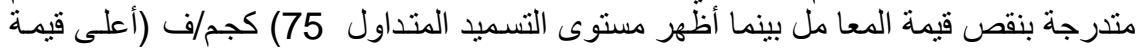

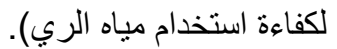

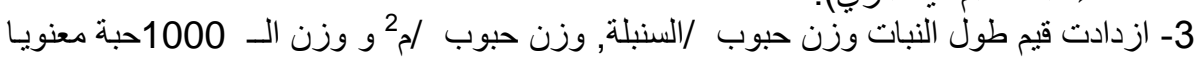
مع زيادة قيمة معامل وعاء البخر القول القياسي.

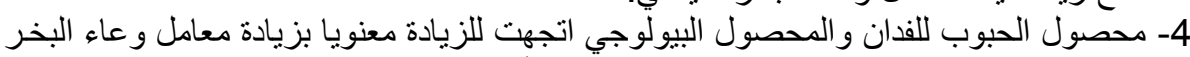

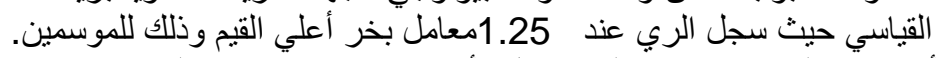

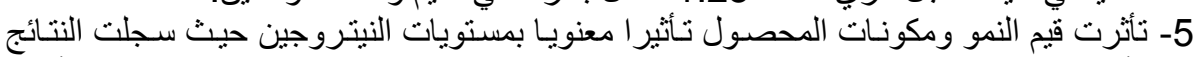

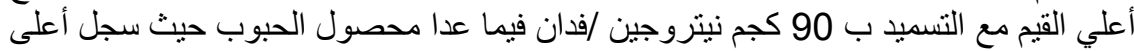

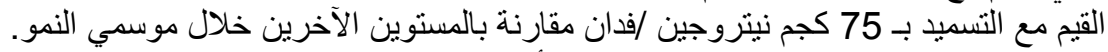

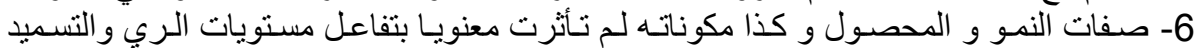

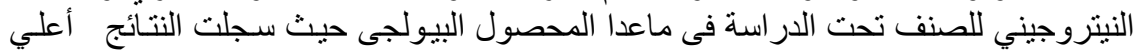

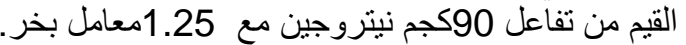

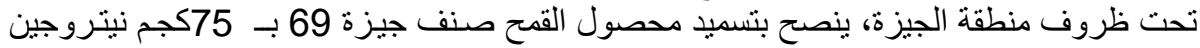

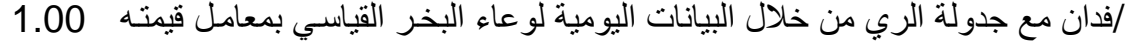

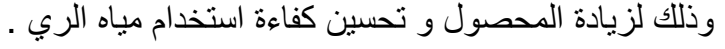

كلية الزراعة - جامعة المنصورة

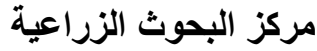

قام بتحكيم البحث

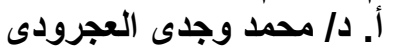

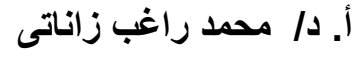


J. of Soil Sciences and Agricultural Engineering, Vol. 1 (1), January, 2010 
Poraas, M. M. E. et al. 
J. of Soil Sciences and Agricultural Engineering, Vol. 1 (1): 49 - 64, 2010

Table (6): Crop Coefficient (Kc) and ETo ( $\mathrm{mm} / \mathrm{month})$ estimated by some ET formulas for wheat at Giza region in 2005/2006 and 2006/2007 seasons

\begin{tabular}{|c|c|c|c|c|c|c|c|c|c|c|c|c|c|}
\hline \multicolumn{2}{|c|}{ Season } & \multicolumn{6}{|c|}{$2005 / 2006$} & \multicolumn{6}{|c|}{$2006 / 2007$} \\
\hline \multirow[t]{2}{*}{ Month } & \multirow[t]{2}{*}{$\mathrm{Kc}$} & \multicolumn{2}{|c|}{$\begin{array}{l}\text { Modified } \\
\text { Penman }\end{array}$} & \multicolumn{2}{|c|}{$\begin{array}{l}\text { Penman } \\
\text { Monteih }\end{array}$} & \multicolumn{2}{|c|}{$\begin{array}{c}\text { Doorenbos- } \\
\text { Pruitt }\end{array}$} & \multicolumn{2}{|c|}{$\begin{array}{l}\text { Modified } \\
\text { Penman }\end{array}$} & \multicolumn{2}{|c|}{$\begin{array}{l}\text { Penman } \\
\text { Monteih }\end{array}$} & \multicolumn{2}{|c|}{$\begin{array}{c}\text { Doorenbos- } \\
\text { Pruitt }\end{array}$} \\
\hline & & ETO & ETc & ETO & ETc & ET0 & ETc & ETO & Etc & ETO & ETc & ETO & ETc \\
\hline Dece. & 0.35 & 71 & 25 & 57 & 20 & 63 & 22 & 74 & 26 & 61 & 21 & 60 & 21 \\
\hline Jan. & 0.45 & 68 & 31 & 52 & 23 & 62 & 28 & 66 & 30 & 53 & 24 & 68 & 31 \\
\hline Feb. & 0.90 & 72 & 65 & 68 & 61 & 104 & 94 & 70 & 63 & 68 & 61 & 104 & 94 \\
\hline Mar. & 1.14 & 93 & 106 & 106 & 121 & 115 & 131 & 112 & 128 & 110 & 125 & 121 & 138 \\
\hline April & 0.85 & 111 & 94 & 142 & 121 & 145 & 123 & 104 & 88 & 138 & 117 & 153 & 130 \\
\hline May & 0.45 & 9 & 4 & 11 & 5 & 12 & 5 & 9 & 4 & 10 & 5 & 18 & 8 \\
\hline Total & & 424 & 325 & 437 & 351 & 502 & 403 & 435 & 339 & 440 & 354 & 524 & 421 \\
\hline
\end{tabular}

